\title{
ANALYZING INFLUENCE OF MUSIC IN DEVELOPING LANGUAGE YOUNG LEARNERS
}

\author{
Agung Assadilah ${ }^{1}$, Nurahman Barokah ${ }^{2}$ \\ ${ }^{1}$ IKIP Siliwangi \\ ${ }^{2}$ IKIP Siliwangi \\ 1Agungassadillah15@gmail.com, ${ }^{2}$ Nurrahman878@gmail.com
}

\begin{abstract}
The purpose of this study to determine the effect of music in language learning against young students in one primary school in Batujajar Kabupaten Bandung Barat. Some of the things that become the focus in this research is how much influence created from music when applied in language learning especially for young learners. This study uses case study design. The subject of this research is the some students of first grade of elementary school. Subjects were analyzed based on their abilities after the application of this study and any positive impact that arose from young learners after the study. And reported descriptively. After analyzed the data shows the influence of music, that students look more excited in the process of learning the language. The data also indicated that some students be able to showed cheerfulness and showed good interaction with the other students. With reference to the findings suggested to teachers to teach the language especially to young learners can use the music as a support in the teaching process.
\end{abstract}

Keywords: Music, Language, Young Learner

\section{INTRODUCTION}

Music has long existed and is attached to our daily activities. Music is like a normal thing played in any activity, moreover music currently can be used as a supporting in the process of learning and teaching in the world of education, especially in teaching young learners. Music contributes as a tool to help make it easier for teachers to apply the learning materials in the classroom. Many previous study has proven that there are many positive benefits in the application of music in the world of education, such as increasing the creativity and ability of young learners, and also increasing social interaction among fellow students, this is also supported by (Hallam, 2012) all the areas of education that music has an impact on, including language skills, numeracy, creativity, social development, and overall intellectual development. Music is also believed to be able to develop young learners learning capabilities who are in development period. As stated by (Stone, 2015) that music can impact a child's learning abilities in more ways than just literacy, proving that music can be a vital asset in all learning environment.

Along with the increasing level of education in Indonesia and the need for learning is also increasing, especially in the context of the language, it can be seen that there are still many young learners who have difficulty in following the language learning in class. Then have an impact when they have a conversation with the other person, there are some young learners who are difficult to say a word that he wants to convey, and some are still stammered to say a sentence, it's all due to several factors that can influence it, such as the limitations vocabulary, the influence of regional languages, untrained language, and many more. Many previous studies have discussed how to improve language learning especially for young learners, some of whom 
chose music to improve their language skills. Based on the results of several studies about how music improves the language skills of children they find many positive effects of the application of music in the field of education, among others has been stated by (Hicks, 2003) that children who are musically trained have more activation in these prefrontal areas than to their peers. Based on the scientific assertion that children who are trained in music during the learning process can affect activation in the prefrontal area, the prefrontal area is part of the lobe associated with the planning process, problem solving, personality, selective attention, organizing. According to (Stuff \& Benson, 1987) that the prefrontal area is a part of the brain that regulates or assesses all the activities of the nervous system. Its means how positive the music affects the brain, and when applied in the learning process it will be easier for teachers to improve a skill in young learners.

Then some other experts argue the same thing that music can have a positive impact on the brain and also improve students' reading comprehension. (Stone, 2015) states that research studies have found that children who participate in music instruction tend to score higher on tests of reading comprehension than children who do not participate in musical instruction. From the results of this study we can conclude that music is not only able to improve language learning but also can have a positive effect on the brain and can also improve reading comprehension for students.

Based on previous studies that have explained the positive impacts and benefits of music in the application of learning, this study aims to further examine the impact and other influences on music especially on the context of the language of young learners in a school in Batujajar Kabupaten Bandung Barat, this study more focuses on the subject of first grade elementary school students because many of them are still difficulties in language learning.

\section{Music}

Music has become a means of entertainment in all walks of life, not only consumed by the upper middle class only, but the music is also very loved by people who have low social status. According to (Banoe, 2003) music derived from the word muse is one of the gods in ancient Greek mythology for branches of art and science, god of art and science. And music is an art branch that discusses and determines the various sound patterns that can be understood and understood by humans. The relationship between music and humans, without us knowing music has an important role in human life, but otherwise will not create music if there is no human activity, and there may be no sound or music created. Humans can be regarded as a source of music because of the creation of sound or music due to human activity, whether intentional or unintentional. A person's intelligence affects the creation of a sound or music, naturally god gives us creativity in developing everything, as well as in developing music. Besides, the creation of music can affect the process of human thinking, (O'Sullivan, 1991) suggests that music affects imagination, intelligence and memory, and also affects the pituitary in the brain to release endorphins. This proves that music and humans each have interrelated roles and are difficult to separate. Then this study was continued by several other scientists to discover the relationship and influence of what is created by the music to humans, research conducted by (Siegel, 1999) stated that music can play a role in the process of maturation of right hemispheres of the brain. Hemispheres are part of the brain that plays an important role in the process of emotional development, which is essential for human development. 


\section{Characteristics of Young Learners}

Young learners are children aged from the first year of formal school (aged four or five years) to age eleven or twelve. According to (Bensom, 1967) that young learners have some characteristics such as young learners are developing conceptually, children's have no real linguistic, young learners are still developing, and children or young learner get bored easily. Based on the characteristics mentioned by Clark confirming the differences between young learners and adult learners, in terms of development, young learners will grow faster if they follow the conceptualized learning, so their reasoning is fixed on one outcome, not branching so they are not confused to follow the learning process. And the teacher must remember that young learners are very bored easily, this requires a teacher to always be innovative and creative in giving lessons to young learners, some of the main issues that is a teacher always use the same methods and media in teaching children, when one of the characteristics of young learners is that they always want to get new things, they always feel curious, this means there must be a new media or method so that children are not easy to feel bored.

\section{Language Acquisition}

According to (Chomsky, 1972) language acquisition is a hypothetical tool that is embedded in the brain that helps children learn languages quickly. Language acquisition or first language acquisition usually occurs during childhood and is a process of unconscious language acquisition.

Based on these statements Chomsky also explains how wonderfully children to gain language skills and also considers the innate understandings of grammar and syntax that all children have. Indirectly the theory stated by Chomsky explains that every child has the ability to acquire language from birth.

\section{Music in education}

At this time the development of music, especially in Indonesia showed rapid progress. In addition to the entertainment media, currently music can be used in education, because it has been shown to have a positive impact for students. This is supported by (Stone, 2015) statement that scientific research supports the use of music in early literacy instruction and also provides evidences for the positive impact of music instruction on early literacy skills. Based on the statement Tammy stone music can positively affect the early reading skills for students, but in addition there are still many positive effects of music that can be developed more deeply to improve the quality of learning for students. Some other experts have proven based on the research they have done on the positive impact of music, (Hallam, 2012) describes how music's effects on language skills then directly affect the development of reading. This means that music can affect the ability of the language and simultaneously able to affect the development of reading someone, in other words the positive influence of music can improve the ability of two skills simultaneously, and this is very useful for teachers who are still difficult to improve student skills.

(Hallam, 2012) has proven through experiments performed on early children aged three to four years, that music can enhance creativity, she has a group of pre-school children involved in 
singing classes as well as on other musical activities, and concludes that when compared to other children who are not involved in any musical activity, musical groups scored higher in creativity, abstract thinking, and improvisation. In this study it is clear that there is a significant difference between students who participate in music activities, with students who are not participating in music activities, that students who follow singing classes or other activities on music get higher creativity value, and also more clever in improvising. Based on previous research data that proves how music plays an important role in human life, not only play a role in the development of the human brain, but music can also improve a person's language skills, reading ability, can even give a positive effect on children's creativity.

\section{METHOD}

On this study, Researcher using Qualitative method, 'Qualitative method is a type of social science research that collect and works with non-numerical data and that seeks to interpret meaning from these (Sigurdartotir, 2012)ata that help us understand social life throught the study of targeted populations or places, (Crossman.A, 2017), the process of research and data retrieval in this study was conducted in one of the primary schools on Bandung Barat. This research was applied based on expert information, for example : The use of song for learning english (Salcedo, 2007) or even learning language for general, although some of these studies mention motivation. And the last, this study was choosen based on, (Sigurdartotir, 2012) "when children start their foreign language, using music or songs should be general activity because it has so many qualities that will engage students and make them more positive toward learning languages. Observations were made for the purpose of this study. The aims of this research is to analyze whether music can be an influence in the development of language learning for young learners, and wheter by listening music students can be motivated to develop their language learning especialy foreign language.

Subject in this study there are 5 participant, they are student from 1 grade elementary school on Batujajar Kabupaten Bandung Barat. For a contributory factor in this study is in need of observation as research data collection procedures, including :

a. Observer interviewed the teacher from the classroom to capture 5 research subjects. 5 subjects in the finding and then elected are 5 students who used to listen to music as a habit or those who perform music lessons outside school activities and those selected are students whose learning ability is more prominent in the appeal of other students in the class.

b. After the election of 5 students as subjects then the observer conducted an interview to the parents of the five students.

c. And the last observer conducted an interview on the five subjects for the purpose of taking and processing research data.

Interviews are used as an instrument in this study, there are two types of interviews used for the acquisition of data, ie interviews to 5 students as subjects and interview to the parents of each of these students. 


\section{RESULTS AND DISCUSSION}

\section{Results}

To find the appropriate data acquisition based on the main objective of this research is for Analyzing Influence Of Music In Developing Language Young Learners, the main focus to find data acquisition is to interview 5 students and also interview the parents of each student.

\section{Interview for Parents}

To interview the parents of the subjects, researchers asked four questions. The first question is "when did you introduce music to your child?" These questions are intended to know the background of musical knowledge of the research subject, Second question is "what kind of music do you introduce to your child?" then "what is your purpose to introduce music to your child as an educational purpose?" This question is asked to know the purpose of parents to introduce music to children, whether as a supporter in interest in learning or just for entertainment. And the next question is "Do you agree if music can develop children's learning motivation, especially language lessons?" in this question if the parent agrees and gives reasons then it will be continued to the last question, the last question is "what impact do you realize from the statement in the previous question?", from this last question the acquisition of the analytical data will be obtained based on the parents' statement.

\section{Interview for Students}

The main focus for data retrieval in this study is in the interview section on the students because the data can be though if based on the answers and statements of the subjects ( 5 students). In this interview the researcher gave 5 questions to each subject which then the answer of each subject will be analyzed and though for the purpose of this research. On the question "Do you like language lessons?", "Do you like foreign language lessons?" both of the questions submitted to see the response of students about language, then proceed to the question "Do you like music?" and "Do you like to learn language lessons using music?" simple questions but answers from students will determine the main purpose of this study which aims to find how music can be motivated in language lessons in students based on Hilda F Israel (2017) Language acquisition has a profound relationship with music in that they can both develop and support each other. The last question "What song do you like? and try to explain what the song means!" from the answers given by the student researchers will find evidence of the positive influence of music on language learning of young learners.

The answers from questions on interviews for parent subjects can be taken from the main point, the results of the interview can be seen in the following table: 
Table 1. Parents Interview

\begin{tabular}{|c|c|c|c|c|c|c|c|}
\hline \multirow{2}{*}{ NO } & \multirow{2}{*}{ QUESTIONS } & \multicolumn{5}{|c|}{ ANSWER } & \multirow{2}{*}{ INFORMATION } \\
\hline & & Student A & Student B & Student C & Student D & Student E & \\
\hline 1 & $\begin{array}{c}\text { Do you like } \\
\text { language lessons? }\end{array}$ & YES & YES & YES & YES & YES & $\begin{array}{c}\text { All students responded } \\
\text { positively to the first } \\
\text { question }\end{array}$ \\
\hline 2 & $\begin{array}{l}\text { Do you like foreign } \\
\text { language lessons? }\end{array}$ & Yes, I like & Yes, I like & Yes, i like & Not too & Yes,I like & $\begin{array}{l}\text { Can be stated that all } \\
\text { students are interested } \\
\text { in language learning }\end{array}$ \\
\hline 3 & Do you like music? & YES & YES & YES & YES & YES & All students like music \\
\hline 4 & $\begin{array}{c}\text { Do you like to learn } \\
\text { language lessons } \\
\text { using music? }\end{array}$ & YES & YES & YES & YES & YES & $\begin{array}{l}\text { All students agree and } \\
\text { can be concluded that } \\
\text { music can motivate } \\
\text { their language } \\
\text { learning }\end{array}$ \\
\hline 5 & $\begin{array}{l}\text { What song do you } \\
\text { like? and try to } \\
\text { explain what the } \\
\text { song means! }\end{array}$ & $\begin{array}{c}\text { (Twinkle } \\
\text { Twinkle) } \\
\text { Student } \\
\text { explanation : } \\
\text { (many stars } \\
\text { sparkling in the } \\
\text { skv) } \\
\end{array}$ & $\begin{array}{c}\text { (Let it Go) } \\
\text { Student } \\
\text { explanation : (its } \\
\text { want to free ) }\end{array}$ & $\begin{array}{l}\text { (You are my } \\
\text { shunshine) } \\
\text { Student } \\
\text { explanation : (you } \\
\text { are my dear) }\end{array}$ & $\begin{array}{c}\text { (Twinkle } \\
\text { Twinkle) } \\
\text { Student } \\
\text { explanation : (The } \\
\text { stars so beautiful) }\end{array}$ & $\begin{array}{c}\text { (Old Mc.Donald) } \\
\text { Student } \\
\text { Explanation : } \\
\text { (Uncle } \\
\text { McDonald had a } \\
\text { large farm) }\end{array}$ & $\begin{array}{l}\text { Although they do not } \\
\text { understand the } \\
\text { meaning of the song } \\
\text { but they understand a } \\
\text { little bit the meaning } \\
\text { of the song they like }\end{array}$ \\
\hline
\end{tabular}

Based on the above table, starting from the answer to the first question, the parents of the B and $C$ subjects answered from 3 years old, from this answer can be concluded that the subject has been introduced to the music long before their mindset can receive formal education, while the parents of the subjects A, D and E answered from 5-6 years old, can be concluded at that age is the right age for children to receive formal education. Continued to answer of the second question ,Parents A, B, C, D and E answered Children Song, which is indeed the type of music is very suitable for use as a medium of learning support, and in the third question, 4 out of 5 parents of the subjects responded that their purpose of introducing music to their children was for educational purposes. Then in the fourth question the parents of the subjects A, B, C, D and $\mathrm{E}$ agree that music can be a motivation for the development of language learning in children. And in the last question the parents of the subjects A, B, C, D and E give different statements, yet from their statements can be concluded that music can have a positive impact on language learning of children.

Important point in this research is the answer from the interviews to the subject indicated in the following table: 
Table 2. Student Interviews

\begin{tabular}{|c|c|c|c|c|c|c|c|}
\hline \multirow{2}{*}{ No } & \multirow{2}{*}{ QUESTIONS } & \multicolumn{5}{|c|}{ ANSWER } & \multirow{2}{*}{ INFORMATION } \\
\hline & & Student A & Student B & Student C & Student D & Student E & \\
\hline 1 & $\begin{array}{c}\text { Do you like } \\
\text { language lessons? }\end{array}$ & YES & YES & YES & YES & YES & $\begin{array}{c}\text { All students responded } \\
\text { positively to the first } \\
\text { question }\end{array}$ \\
\hline 2 & $\begin{array}{l}\text { Do you like foreign } \\
\text { language lessons? }\end{array}$ & Yes, I like & Yes, I like & Yes,ilike & Not too & Yes, I like & $\begin{array}{l}\text { Can be stated that all } \\
\text { students are interested } \\
\text { in language learning }\end{array}$ \\
\hline 3 & Do you like music? & YES & YES & YES & YES & YES & All students like music \\
\hline 4 & $\begin{array}{c}\text { Do you like to learn } \\
\text { language lessons } \\
\text { using music? }\end{array}$ & YES & YES & YES & YES & YES & $\begin{array}{c}\text { All students agree and } \\
\text { can be concluded that } \\
\text { music can motivate } \\
\text { their language } \\
\text { learning }\end{array}$ \\
\hline 5 & $\begin{array}{l}\text { What song do you } \\
\text { like? and try to } \\
\text { explain what the } \\
\text { song means! }\end{array}$ & $\begin{array}{c}\text { (Twinkle } \\
\text { Twinkle) } \\
\text { Student } \\
\text { explanation : } \\
\text { (many stars } \\
\text { sparkling in the } \\
\text { sky) } \\
\end{array}$ & $\begin{array}{c}\text { (Let it Go) } \\
\text { Student } \\
\text { explanation : (its } \\
\text { want to free ) }\end{array}$ & $\begin{array}{l}\text { (You are my } \\
\text { shunshine) } \\
\text { Student } \\
\text { explanation : (you } \\
\text { are my dear) }\end{array}$ & $\begin{array}{c}\text { (Twinkle } \\
\text { Twinkle) } \\
\text { Student } \\
\text { explanation : (The } \\
\text { stars so beautiful) }\end{array}$ & $\begin{array}{l}\text { (Old Mc.Donald) } \\
\text { Student } \\
\text { Explanation : } \\
\text { (Uncle } \\
\text { McDonald had a } \\
\text { large farm) }\end{array}$ & $\begin{array}{l}\text { Although they do not } \\
\text { understand the } \\
\text { meaning of the song } \\
\text { but they understand a } \\
\text { little bit the meaning } \\
\text { of the song they like }\end{array}$ \\
\hline
\end{tabular}

Based on table above the subject A, B, C, D and E answered yes, then in the second to the second question, 4 out of 5 subjects gave a positive response. Likewise with the third question, the entire subject gives a positive response because it can be concluded all people like on music. In the fourth question, here shows the influence of music on language learning can trigger student learning motivation because all subjects agree with the questions raised, and in the last question the five subjects expressed different answers and explanations, yet with the analysis done by researchers of the answers that the subject given, can be concluded that the music can motivate language learning on students based on an explanation of the song their like.

\section{Discussion}

Based on the results, its can be seen from the answers given from parents and students, researchers can conclude, children intentionally or unintentionally get an intake of what they listen as an example are children's songs and can also intake they receive is from the movie they watch in which there are songs that use a foreign language, from there they will trying to develop the vocabulary or pronunciation of the lyrics that they listen, even automatically they also develop the ability in the speaking aspect as well, although the subject not too understand all the meaning and intent in the lyrics of the song, but consciously or unconsciously their have done a process. What process have their done? Namely the process of learning foreign language that their often refer to as Listening as usual received by the students and it can be seen also that the parents of the subjects in this study play a role in the motivation of learning his children by introducing music, especially children's songs which gives a positive effect of language knowledge on their children. So in the terms of this learning motivation students in language learning can develop through music as a supporting factor in their learning. 


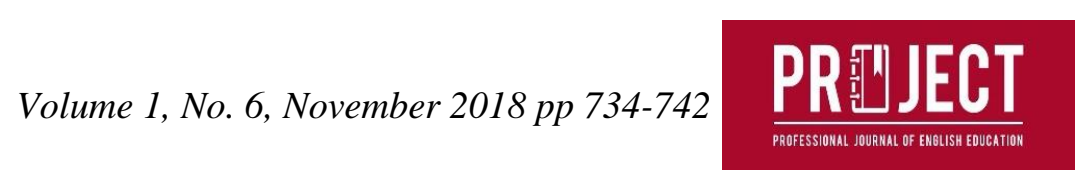

\section{CONCLUSION}

Based on the research that has been done there are some data showing the influence of music in language learning in young learners and the researchers drawn conclusion as follows:

1. Using music in language learning for young learners is very effective for the development of language. Through music or songs, young learner finds many new vocabulary and indirectly affects in language learning.

2. During the research data also showed that many students are more active when learning language using music. Their social interaction to fellow students is very good, this shows that music is also able to increase social interaction and also the activity of students in class.

3. Can be seen the difference between students who like to listen to music with students who do not like listening to music. Students who love listening to music they are more cheerful, they are more able to express their feelings, and also more spirit in learning activities. While students who do not like listening to music show the opposite.

4. Music can also affect the pronunciation of young learners. Recitation of students who often listen to music or songs tend to be better than students who rarely listen to music.

Language learning for children can be through various media of learning and in this research media used is music especially children's songs, children's songs more appropriate because language that used in the lyrics is easy to understand by child or young learnes and children will be more interested because the content of the lyrics in children's songs is fun for them and that will be their motivation in language learning.

\section{ACKNOWLEDGMENTS}

Gratitude Alhamdulillah to the presence of Allah SWT, which provides all the favours of faith, pleasures, health and strength in the preparation of this article. Sholawat and greetings are always poured out to the role model of all time, Prophet Muhammad, along with his family, friends, and his followers. On this very happy occasion, the authors express their gratitude to Cynantia Rachmijati,M.M.Pd as a Supervisor, who always always take the time to give directions, motivation, encouragement, suggestions and research plan until the completion of this article. And to other parties who also helped and helped the completion of this article, may Allah will repay all the good you have given to us. And we hope that this article can be useful in education.

\section{REFERENCES}

Banoe. (2003). The Role Of Music And Songs In Teaching English Vocabulay To Students. Higher School Of Strange Languages Name Of Samuela Bogumila Lindego.

Bensom, W. (1967). Australian joournal of music.

Chomsky, N. (1972). The Effect Of English Songs On English Learners Pronouncation. golestan: Golestan Univercity.

Crossman.A. (2017). Analisis Fraktal Berbagai Jenis Musik. pontianak: Program Studi Fakultas Matematika Dan Ilmu Pengetahuan Alam Universitas Tanjung Negara.

Hallam, S. (2012). The Power Of Music; Its Impact On The Intellectual,Social And Personal Development Of Children And Young People. London: Univercity Of London.

Hicks, M. (2003). Mormonism and Music.

O'Sullivan. (1991). The Relationship Between Music And Language. Zurich: Univercity Of 
Zurich.

Salcedo, R. and. (2007). English Language Through Music And Song Lyrics-The Perfomance Of A Lifetime. New York: Boise State Univercity.

Siegel. (1999). The Impact Of Music Activity On Foreign Language,English Learning For Young Children. Taichung: Chaoyang Univercity Of Technology.

Sigurdartotir. (2012). Musical Intelligence And Foreign Language.

Stone, T. (2015). Influence Of Songs In Primary School Student's Motivation Learning English (Vol. 9). Lima: Universidad Peruana De Ciencias Aplicadas.

Stuff, \& Benson. (1987). Why Use Music In English Language Learning? A Survey Of The Literature. london: King's College London. 